associated. The past year has seen the completion of a series of more self-contained regional library systems. Such a vast scheme of mutually supporting libraries must depend for its greatest efficiency on the maintenance of central catalogues. Union catalogues by authors of the books in the affiliated libraries are being compiled at various centres. The total number of entries in that at the National Central Library has reached million. A subjectcatalogue of books and original articles is maintained at the Science Library and has reached $2 \frac{1}{4}$ million entries. A "Union Catalogue of the Periodical Publications in the University Libraries of the British Isles" was published in 1937. The total number of books lent during that year was nearly 140,000 , of which it is significant that some 400 were supplied to foreign libraries.

\section{Prices of Biological Books in 1937}

For twelve years the Quarterly Review of Biology has analysed and compared the cost to Americans of biological books, based upon the prices of all such received for review by the Quarterly. The analyses have produced some interesting figures regarding the relative cost of books produced by different nations, and to some of them attention has been directed in NatuRE. In point of price, German books are still the most expensive, despite the announced policy of German publishers, a German average of 1.95 cents a page comparing with $1 \cdot 27$ for British books, and 0.85 for French. Than the last the only cheaper books published are those issued by the British Government $(0.34$ cents a page) and the U.S. Government $(0 \cdot 16)$, but since the last three categories are often published in paper covers, some of the saving may be on binding. Comparing 1937 with 1936 , it is remarkable to find that the average price per page from every origin, except Germany and Great Britain, has been lowered -by from about 10 per cent in U.S. books to so much as 79 per cent in British Government official publications. But while the British Government has been so greatly reducing its charges, the ordinary British publishers of biological books have been compelled to increase by 16.5 per cent. However, it is possible that the particular books received by the Quarterly for review do not represent fair samples in every case ; indeed, the total of British Government publications received in all the twelve years only amounts to 8,836 pages, so that, as the authors, Raymond Pearl and Maud DeWitt Pearl, point out, general conclusions must be drawn with caution from this material.

\section{The First Slovakian Polytechnic}

IT is true that, for a country of fifteen million inhabitants, Czechoslovakia is well provided with facilities for higher education. There are four universities, one of which is German, and numerous academies and schools of technology that grant recognized diplomas; but until now there has been no Slovak polytechnic. When the new academic year commences in October, however, this will be remedied by the opening of a polytechnic at Košice, in east Slovakia, to be named after Dr. Milan Stefaník, the
Slovak astronomer who became the first Czechoslovak Minister for War. This technical institute will rank after the Comenius University of Bratislava as the second most important educational establishment in the eastern half of the Republic. The president, Dr. E. Benež, has nominated the principal members of the staff, which will include a number of Slovaks who have graduated in science or technology. Their colleagues will be certain lecturers from the Universities and Polytechnics of Prague and Brno, and the new institute will doubtless soon be able to supply local industrial undertakings with students who have obtained their diplomas at Košice.

\section{The Public Health of India}

THE vital statistics and public health of India are dealt with in the recently published annual report of the Public Health Commissioner with the Government of India for 1935 (Vol. 1. With Appendixes. Delhi : Manager of Publications. 1937. Rs. 2, or 3s. 6d.). The mid-year estimated population was $278,199,545$, the birth-rate and the death-rate per 1,000 were respectively 35 and 24 , and the infantile death-rate per 1,000 live births was 164 (the corresponding rates for England and Wales are 15, 12 and 57). The total mortality from the three principal epidemic diseases-cholera, plague and smallpoxdecreased by 24,000 compared with 1934, but this was more than covered by the large reduction in deaths from plague, which fell from 80,000 in 1934 to 32,000 in 1935. Cholera mortality rose to 217,000 , the highest figure for the past three years. Smallpox caused 91,000 deaths, as against 84,000 in 1934 . Tuberculosis is another disease the incidence of which has increased rapidly during recent years, and which is causing a heavy mortality, particularly in urbanized and industrialized areas. Of fevers, malaria caused the heavy toll of $1,632,000$ deaths. No less than 150,000 women died in childbirth or from causes associated with childbirth. An account is also given of the public health services and administration, and of the work of the laboratories and institutes for medical research.

\section{Institution of Electrical Engineers Awards}

THE following scholarships have been awarded by the Institution of Electrical Engineers for 1938: Ferranti Scholarship (annual value $£ 250$; tenable for 2 years): L. S. Piggott (University of Oxford) ; Duddell Scholarship (annual value $£ 150$; tenable for 3 years) : J. B. Higham (Penarth County School); Silvanus Thompson Scholarship (annual value $£ 100$, plus tuition fees; tenable for 2 years): H. Darnell (Mersey Railway Company); Swan Memorial Scholar. ship (annual value $£ 120$; tenable for 1 year): J. G. Hutton (Sunderland Technical College); David Hughes Scholarship (value $£ 100$; tenable for 1 year): H. E. Newton (University of Sheffield); Salomons Scholarship (value $£ 100$; tenable for 1 year): C. Halliday (King's College, Newcastle-on-Tyne). Grants have been made from the War Thanksgiving Education and Research Fund (No. 1) to J. W. Carroll (King's College, London), to E. Franklin (University of Birmingham), and to G. Y. Shute (University 
College, Nottingham). Thorrowgood Scholarships have been awarded to C. R. Smith (London \& North Eastern Railway), and E. C. Norris (Southern Railway Company).

\section{Indian Cotton}

Technological Crrculars Nos. 323 to 338 issued by the Indian Central Cotton Committee's Technological Laboratory during the first three months of 1938 exemplify very thoroughly the work which is being done in India to improve the cotton crop of the country. Each season early samples of the crops from different parts of the country are sent to the Laboratory for test and each circular summarizes the results obtained in the last six years. No. 336 deals, for example, with a pure line strain isolated in 1931 and grown at the Government Experimental Farm, Akola, where the rainfall is 28 inches per annum, the soil black cotton soil, the growing period from June until November and the maximum temperature varies from $85^{\circ}$ to $115^{\circ} \mathrm{F}$.; weight of cotton per seed, 30 milligrams, of seed, $62 \mathrm{mgm}$. 26 seeds per boll, 16 to 18 bolls per plant; yield, $400-800 \mathrm{lb}$. per acre; 43 thousand acres under cultivation as against 120 acres in 1933. The average length of fibre (staple) is $\frac{7}{8}$ inch, the curve of deviation being approximately the error curve. In manufacture, the percentage of loss from dirt is low, that from carding is normal, about 8 per cent. Fibre strength was best in 1933 and then suitable for yarn of 31 counts, that is, 31 hanks of 480 yards to the pound.

\section{Butterfly Migrations in the Tropics}

THE attention of travellers and residents in the tropics is directed to an attractively produced booklet entitled "Butterfly Migrations in the Tropics", recently published by the British Museum (Natural History). It is written on behalf of the Trustees of the Museum by Dr. C. B. Williams, and is well illustrated by means of five three-colour process plates of typical migrant species. The booklet is issued primarily with the object of obtaining information on the subject of migration. Very little is known relative to this problem in the tropics, and it is easy for any accurate and willing observer to assist in this matter. Instructions are given with regard to the special points upon which information is desired. The booklet may be obtained from the British Museum (Natural History), London, S.W.7, price $9 d$.

\section{International Grassland Congress}

THE report of the fourth International Grassland Congress held in Great Britain in July 1937 under the presidency of Prof. R. G. Stapledon has now been published. The volume, which consists of 486 pages, contains the full texts of all papers, both plenary and sectional, delivered to the Congress at Aberystwyth. Each is printed in English or German with a summary in the alternative language, the main items of the discussion being also included. The report can be obtained from the Joint Secretaries, Fourth International Grassland Congress, Aberyst- wyth, for £2, post paid. A smaller volume (pp. 87), containing abstracts in English and German of the majority of the papers delivered, is available for 58 . post paid.

\section{Work of the Central Midwives Board}

The report of the Central Midwives Board, recently issued, reviews the work of the Board during the year ended March 31, 1937. The Midwives Roll contained the names of 65,046 women, a net increase of 2,982 on last year's roll. During the year, only 18 midwives were dealt with by the Board under its penal powers on charges of malpraxis, negligence or misconduct, as a result of which seven names were removed from the roll. The Minister of Health approved the revised rules for training and examination, on the preparation of which the Board has been engaged for a considerable time. The two most important changes effected by the new rules are (a) an extension of the period of training from 6 to 12 months for State-registered general trained nurses, and from 12 to 24 months for other pupilmidwives, and $(b)$ division of the course of training into two parts, each of which will be completed by an appropriate examination. An important decision during the year was the permission given to midwives to administer nitrous oxide and air to women in childbirth, under certain conditions.

\section{Congress of Electroradiology}

THE fourth annual Congress of French-speaking Electro-Radiologists will be held in Paris on October 5-8. At the opening meeting, Prof. Joliot-Curie will lecture on neutrons and artificial radio-elementsbiological applications and therapeutical hypotheses. The following subjects will also be discussed: the results of radiological methods of examination; the bio-electric phenomena of the nervous system, present state of the question and possible application; anti-inflammatory roentgentherapy; biological action of rays and high-frequency currents; progress of histo-radiography; fresh data on neuro-muscular stimulation; interpretation of electrotoric phenomena. The subscription is 100 francs, which should be sent to Dr. Morel Kahn, 45 rue Scheffer, Paris $16^{\mathrm{e}}$. Further information can be obtained from Dr. Delherm, 1 rue Loas Cases, Paris $7^{e}$.

\section{Studentships and Fellowships in Medical Research}

THE Medical Research Council invites applications for a third series of studentships and fellowships intended to encourage young British medical graduates towards becoming investigators in those branches of medical science which are concerned directly with disease as it occurs in human beings. Post-graduate studentships are offered for medical graduates who have already held house appointments and are strongly inclined to a career in clinical science or experimental pathology. Each selected student will receive a stipend at the rate of $£ 200$ per annum, during a period not exceeding twelve months, for personal maintenance while undertaking approved courses of study in Great Britain such as may be 